\title{
LAMP CONTROL SYSTEM THROUGH ANDROID AND WIFI BASED ON ARDUINO MICROCONTROLLER
}

\author{
Ricky Ramadhan Harahap ${ }^{1 *}$, Mahardika Abdi Prawira Tanjung ${ }^{2}$, Barany Fachri ${ }^{3}$ \\ ${ }^{1,3}$ Sistem Komputer, Universitas Pembangunan Panca Budi \\ ${ }^{2}$ Sistem Informasi, STMIK Royal Kisaran \\ email: rickram0704@gmai.com
}

\begin{abstract}
The rapid development of digital technology has also contributed to the development of computer technology. Nowadays, many electrical devices work integrated with computer systems. This of course will greatly help human work in operating these electrical devices. One of the research that is currently being devel-oped is about Smart Home. Smart Home has several benefits such as providing better comfort, more guaranteed safety and security, and sav-ing electricity use. By implementing Smart Home devices in homes or offices, electrical devices will be able to work au-tomatically according to user needs. Us-ers can also monitor and control electrical devices in the house remotely through a communication channel such as through the internet network, Wi-Fi or bluetooth. The special properties of a microcontrol-ler, which are small in size, save electrical power and flexibility, make the microcon-troller very suitable for use as a data re-corder / recorder in applications that do not require the presence of an operator.
\end{abstract}

Keywords: Arduino-Uno; ESP8266; IOT; Relay; Wifi

\begin{abstract}
Abstrak: Perkembangan teknologi digital yang pesat juga turut berkontribusi pada perkembangan teknologi komputer. Saat ini banyak perangkat listrik yang bekerja terintegrasi dengan sistem komputer. Hal ini tentunya akan sangat membantu pekerjaan manusia dalam mengoperasikan perangkat listrik tersebut. Salah satu penelitian yang sedang dikembangkan adalah tentang Smart Home. Smart Home memiliki beberapa keunggulan seperti memberikan kenyamanan yang lebih baik, keamanan dan keselamatan yang lebih terjamin, serta penghematan penggunaan listrik. Dengan mengimplementasikan perangkat Smart Home di rumah atau kantor, perangkat listrik akan dapat bekerja secara otomatis sesuai kebutuhan pengguna. Pengguna juga dapat memantau dan mengontrol perangkat listrik di rumah dari jarak jauh melalui saluran komunikasi seperti melalui jaringan internet, Wi-Fi atau bluetooth. Sifat khusus dari mikrokontroler yaitu ukurannya yang kecil, hemat daya dan kelenturan listrik, menjadikan mikrokontroler sangat cocok digunakan sebagai rekorder / perekam data pada aplikasi yang tidak membutuhkan kehadiran operator.
\end{abstract}

Kata kunci: Arduino-Uno; ESP8266; IOT; Relay; Wifi 


\section{INTRODUCTION}

In the era of analog technology development, in general, electrical devices are controlled conventionally by the user. One must turn on and off the switch directly connected to the electrical device. Sometimes, there are some electrical devices that are still alive when not in use, this can be caused by the user's negligence to turn off the electrical device. If the number of electrical devices in a house is large enough, it will be very ineffective and uncomfortable to turn off and turn on these electrical devices conventionally. The use of electrical energy from these devices will also be inefficient [1].

The rapid development of digital technology has also contributed to the development of computer technology. Nowadays, many electrical devices work integrated with computer systems. This of course will greatly help human work in operating these electrical devices. One of the research that is currently being developed is about Smart Home. The Smart Home device is a device that has a very sophisticated automation system for controlling lights and temperature, a multi-media device for monitoring and turning on a security system connected to a door or window and several other functions [2].

Smart Home has several benefits such as providing better comfort, more guaranteed safety and security, and saving electricity use [3]. By implementing Smart Home devices in homes or offices, electrical devices will be able to work automatically according to user needs. Users can also monitor and control electrical devices in the house remotely through a communication channel such as through the internet network, Wi-Fi or bluetooth.

Microcontroller is a device used to control a process or aspects of the environment. Microcontrollers are usually used for equipment that does not really need high processing speeds. The special properties of a microcontroller, which are small in size, save electrical power and flexibility, make the microcontroller very suitable for use as a data recorder / recorder in applications that do not require the presence of an operator [4].

Arduino Uno is a circuit board based on the ATmega328 microcontroller. This IC (integrated circuit) has 14 digital inputs / outputs (6 outputs for PWM), 6 analog inputs, a 16 $\mathrm{MHz}$ ceramic crystal resonator, USB connection, adapter socket, ICSP header pins, and a reset button. Arduino Uno itself uses the ATmega 328 microcontroller chip as the center of its control. This chip is attached to the socket header on the Arduino Uno board so that it can be removed and reinstalled. The advantage is that if there is damage to the chip caused by failure or 'physical injury' (dropping or slamming) then you can replace the damaged chip with a new chip. So you don't need to replace your Arduino Uno board as a whole so you can save damage costs.

The ESP8266 Wifi connection is SOC (System on Chip), so we can do programming directly to the ESP8266 without requiring an additional microcontroller. Another plus, this ESP8266 can play the role of both an adhoc access point and a client at the same time [4]. By utilizing the advantages of Wifi ESP8266 it is possible to connect Arduino Uno to android devices. 
DOI: https://doi.org/10.33330/jurteksi.v6i3.866

Available online at http://jurnal.stmikroyal.ac.id/index.php/jurteksi

\section{METHOD}

\section{Research Workflow}

This research workflow begins with the stage of identifying a problem to be researched, then carrying out a literature study related to the problem to be studied followed by determining the research objectives so that the research does not spread to other scopes, then collecting data or samples to be studied is continued. by designing and implementing using samples that have been collected where the design and implementation are in accordance with predetermined research objectives. Then, the method that has been designed and implemented is tested and in the final stage, the analysis and evaluation of the method is carried out so that conclusions can be drawn on the research.

System Planning Lamp Control Diagram Design Scheme

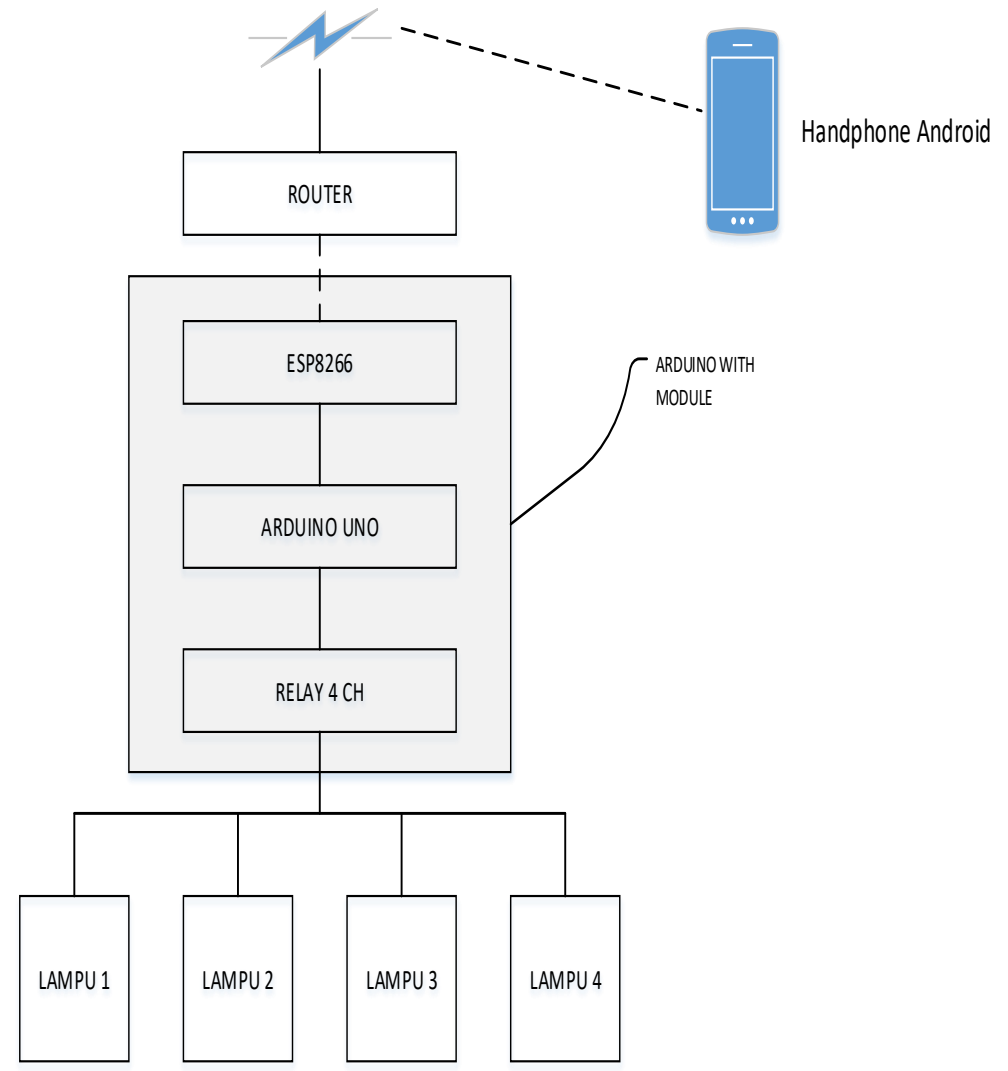

Image 1. Lamp Control Diagram Design Scheme

This study designed a lamp controller with Android and used the esp 8266 wifi module and connected the lights to a 4 channel relay as shown in Figure 1. Android phones use the 8266 wifi module to enter the Android hotspot network. By using the AT
Command command on the esp8266 wifi module, you can find out the IP address obtained. Then open the android application that has been designed on the android mobile to control the light relay based on the IP address that has been obtained. 
DOI: https://doi.org/10.33330/jurteksi.v6i3.866

Available online at http://jurnal.stmikroyal.ac.id/index.php/jurteksi

\section{Flashing Firmware ESP 8266}

Before you can use the esp 8266 module on Arduino and relay, the esp 8266 wifi module must be flashing first.
Flashing is done to enter AT commands and wifi functionality on esp 8266 . Here is the arrangement of the circuit

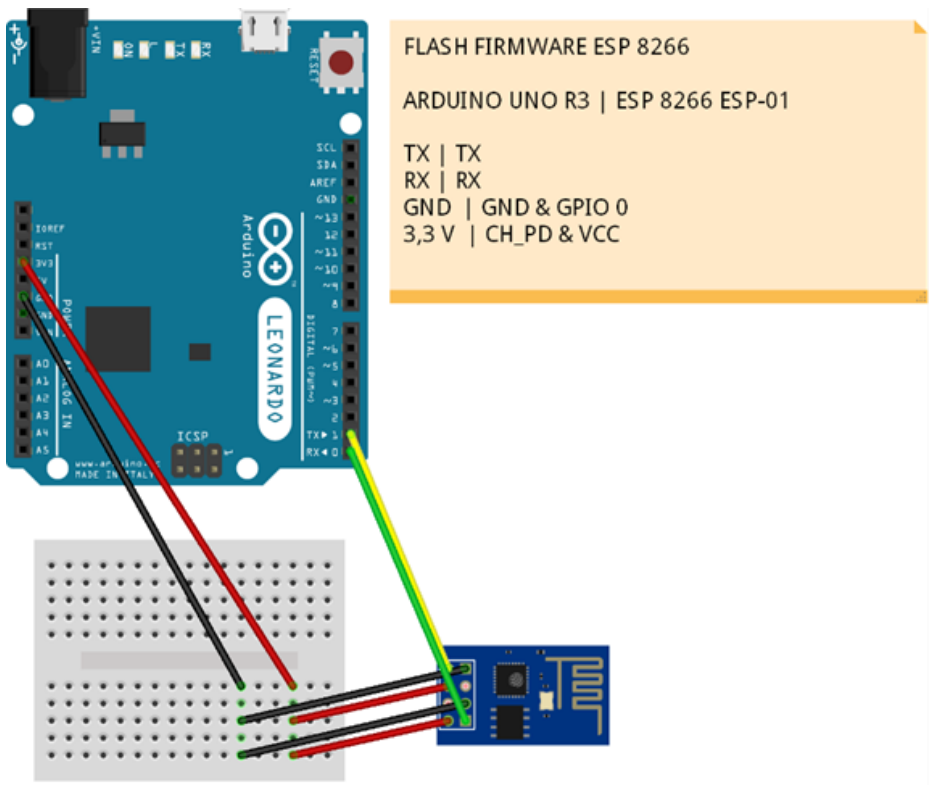

Image 2. Network Setting Flashing Firmware esp8266

Light Controller Network
$\begin{aligned} & \text { Arrangement } \\ & \text { After flashing the firmware on }\end{aligned}$
to be connected. Here is the
arrangement of the series.
the esp8266 module, then arrange a

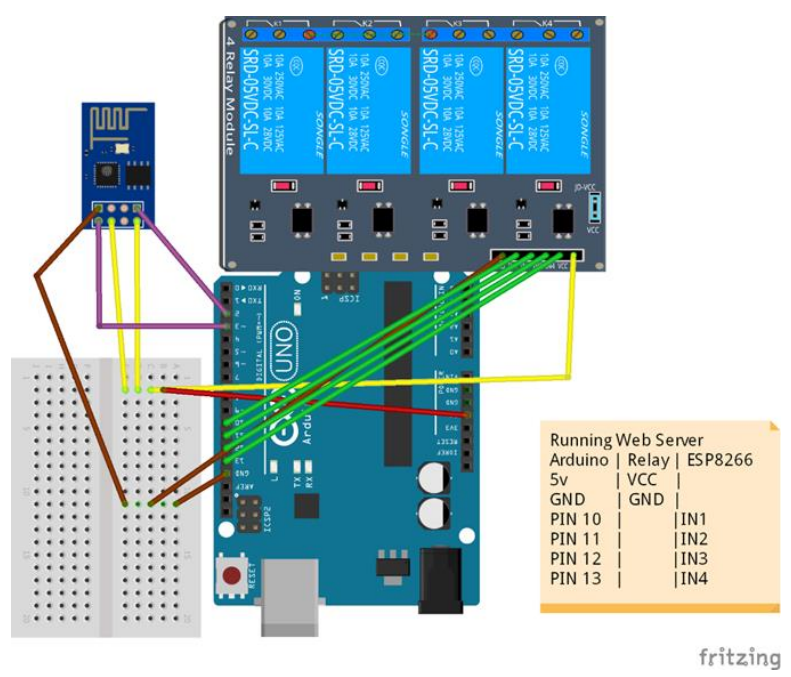

Image 3. Light Controller Network Arrangement 
DOI: https://doi.org/10.33330/jurteksi.v6i3.866

Available online at http://jurnal.stmikroyal.ac.id/index.php/jurteksi

\section{Android System Interface Design}

To be able to control the lights via an android phone, it is necessary to design an application on the android phone. Here is the android application design.

In Figure 4 is the main display design of an android application for a lamp controller using the Inventor 2 app. Seen in Figure 3.4 the on and off buttons will be used to control the lights in the Arduino Uno circuit, relay and the esp8266 wifi module.

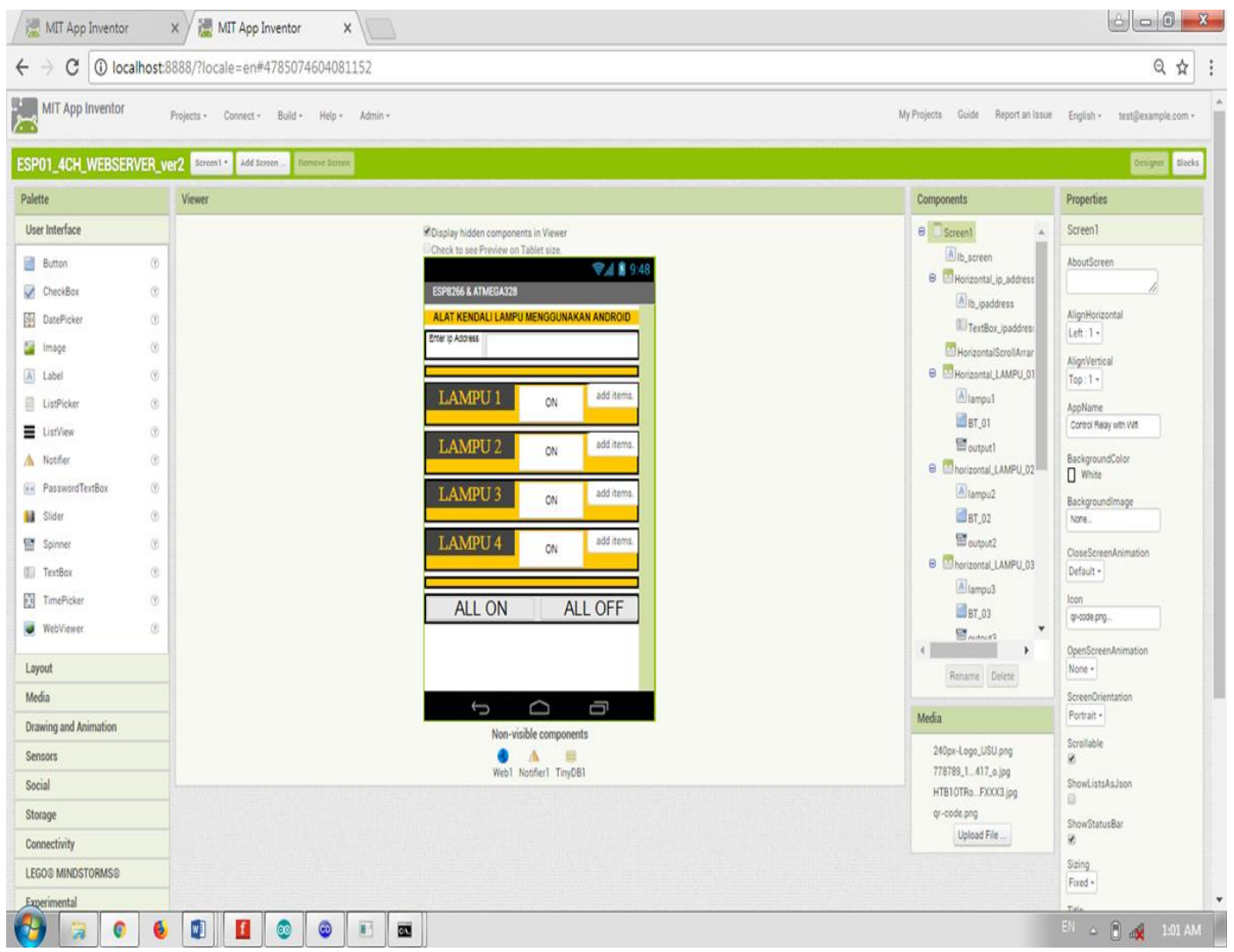

Image 4. Android System Interface Design

\section{RESULT AND DISCUSSION}

\section{The initial view of the application}

In Figure 5, you can see the IP address obtained on testing with Arduino software. The ip address is used to control lamp 1, lamp 2, lamp 3 and lamp 4 on the relay.
In Figure 5 when starting the application, a request will appear to fill in the ip address carried out by Notifier1. Then the programming of buttons one to four starts with Button Number 1 (BT_01) to Button Number 4 (BT_04 
Vol. VI No. 3, Agus 2020, hlm. 293 - 299

DOI: https://doi.org/10.33330/jurteksi.v6i3.866

Available online at http://jurnal.stmikroyal.ac.id/index.php/jurteksi
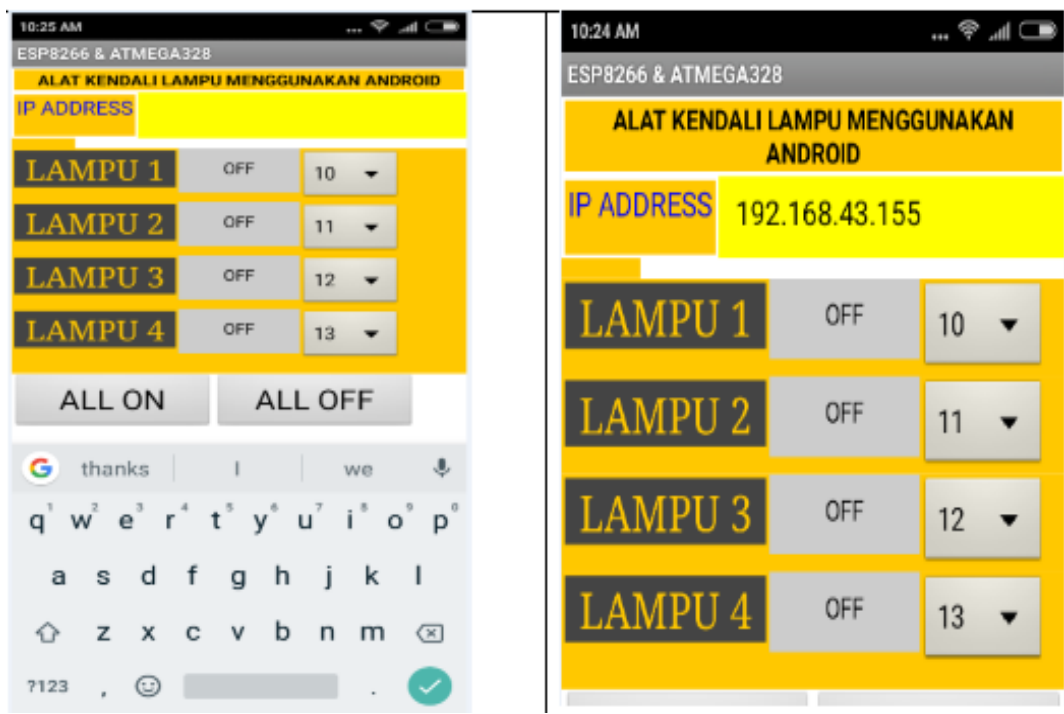

Image 5. the initial view of the application

\section{Test Result}

When Button Number 4 (BT_04) is pressed, the off button with Background Color which is initially gray will set the text to $\mathrm{ON}$ in green, then the program will continue to web1 where this command will send the command to the selected Pin, on button 4 the selected Pin is 13 , when the command has been sent by web1 it will proceed to esp8266 with a display on the serial monitor as shown. When Button Number 3 (BT_03) which has the text $\mathrm{ON}$ is pressed, the green background color will turn red and the text will turn OFF.

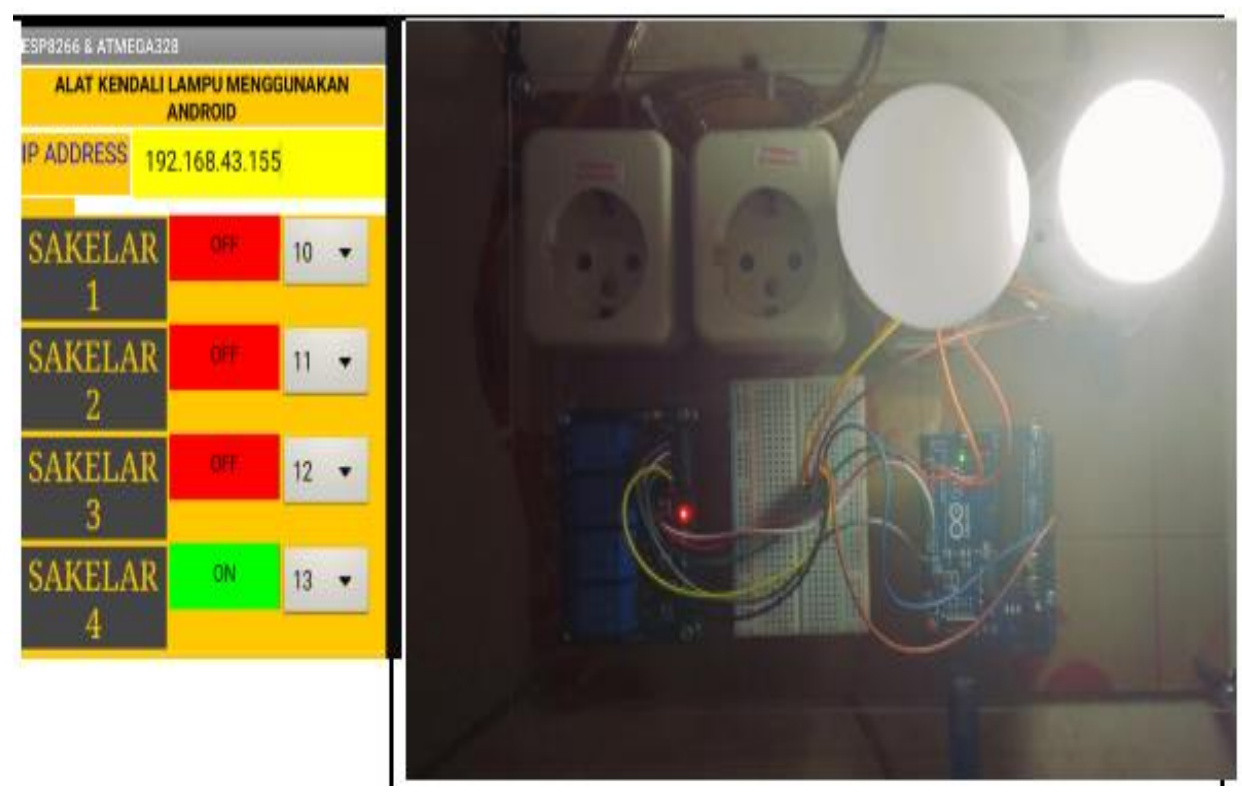

Image 6. When Switch Four Is Pressed, The Light Turns On 
DOI: https://doi.org/10.33330/jurteksi.v6i3.866

Available online at http://jurnal.stmikroyal.ac.id/index.php/jurteksi

\section{CONCLUSION}

The ESP8266 module is a very inexpensive but truly effective platform for communication or control via the internet, whether used standalone or by using an additional microcontroller in this case the Arduino as the controller. This module is very dependent on the received wifi frequency so that it causes dependence on a stable wifi frequency. Adding the number of switches used can be done by adding the relay module.

With advances in technology, esp8266 has appeared with different types according to the needs of use in this research, for example, there are types that already exist in Arduino, there is also a tool that can simplify the flashing process with nodeMCU flasher. Because the esp8266 has a sleepmode, the power source is small so that when using resources such as a battery it can last a long time. This module can also be continued by using wifi which can connect to the internet by creating a website and a server that is used as a connection to hardware.

\section{BIBLIOGRAPHY}

[1] Andrianto, H. \& Darmawan, A., Arduino Belajar Cepat dan Pemograman. Bandung: Informatika, 2016

[2] Santoso, H., Panduan Praktis Arduino Untuk Pemula. Trenggelek:Elang Sakti, 2015.

[3] Kurniawan, H., Mengenal Mikrokontroler Arduino Uno. Malang:Beta Aksara, 2017.

[4] Bahrin, "Sistem Kontrol Penerangan Menggunakan Arduino Uno Pada Universitas Ichsan Gorontalo", ILKOM Jurnal Ilmiah, Vol. 9, No. 3, pp:282-289. 2017 